\title{
A CRITICAL ANALYSIS OF GENDERED STRUCTURAL RESTRICTIONS TO ENTREPRENEURSHIP IN INDIA
}

\author{
Mehr Dewan \\ American Embassy School, Delhi \\ DOI: 10.46609/IJSSER.2020.v05i10.016 URL: https://doi.org/10.46609/IJSSER.2020.v05i10.016
}

\begin{abstract}
Gender-equality is a sensitive and crucial aspect of socio-economic development in India. It has been found that structural barriers to employment and entrepreneurship for women not only contribute to their economic marginalization but also restrict the economic growth of India severely. Indian society has traditionally been aligned with patriarchal principles, which now manifest through traditions, culture, norms, and behavior and prevent women from gaining agency and ascending to positions of power. This paper has analyzed the gendered structural restrictions to entrepreneurship in India and determined that gender-bias against women at the part of investors and venture capitalists, unequal social expectations for child-rearing and housework, the lack of public and workplace safety as well as the manufactured confidence gap deter female entrepreneurship in India. Even though some progress has been made in promoting entrepreneurship amongst women, especially in the informal sector, this progress is caste and class exclusionary and leaves women from low-income and socially disadvantaged communities behind. Lastly, this paper has provided policy recommendations to improve existing inequalities through awareness campaigns, regulations, linkage to the formal economy, and reservation of seats in academic institutions.
\end{abstract}

Keywords: Gender, policy, child, socio-economic, employment.

\section{Introduction}

Entrepreneurship is defined as the process of designing, launching, and running a new business, which is usually small in scale and operations which leads to the creation of economic and social value in society (Diochon \& Andersen, 2011). The ability of people to generate and extract value through entrepreneurship depends significantly on their external environment and is impacted by different social, cultural, economic, and technological developments in industry and society. India has traditionally been a socialist economy- with heavy dependence on state-owned industries, and lack of ability and avenues to actualise entrepreneurial potential. However, the 


\section{International Journal of Social Science and Economic Research}

ISSN: $2455-8834$

Volume:05, Issue:10 "October 2020"

Indian economy was overhauled significantly in 1991 in the midst of a Balance of Payments crisis. That marked a pivotal point in Indian economic history, as subsequent governments across party lines have progressively liberalized the economy to an extent that the Indian economy does not just allow private enterprises to thrive, but also depends on them for continued economic growth and prosperity (Sharma, 2011). Over the past few decades, market disruptions and value creation in India through domestic entrepreneurship has been significant and intensive. The setting up of world-class private and public business schools and different government organizations and programs, such as Startup India has been guided by the understanding of the importance of entrepreneurship in a developing country like India and the need to generate and inculcate entrepreneurial spirit amongst the youth.

Women's empowerment continues to be a crucial challenge for Indian policymakers, especially in states within the 'Hindi Belt' or the Gangetic Plains. The lack of agency at the hands of women combined with their exclusion from socio-economic development and growth is a marker of the denial of fundamental rights guaranteed by the constitution (Thomas, 2016). Entrepreneurship is not only a means to women's empowerment, but also is a metric of the same. The help that entrepreneurs need from society whilst setting up their businesses is largely dependent on their identity which ultimately determines their success and ability to actualize change. The absence of women in entrepreneurship in India is owed to the presence of structural restrictions and barriers- that act through systematic actions and individual behavior. The level of exclusion faced by women is also not uniform and depends on other identity markers such as caste and economic status. Whilst progressive policies of businesses and governments have promoted entrepreneurship amongst urban, upper-class, upper-caste women over the past decade, these changes have neither trickled down to rural and semi-urban contexts nor to women belonging to economically backward or socially marginalized communities. The gendered structural barriers to entry, in these cases, are strengthened by other hierarchical narratives of caste and class.

The World Bank conducted a survey in 2014 to determine rates of participation of Indian women in business and concluded that the percentage of firms with female partnership in ownership is $10.7 \%$ (World Bank, 2014). Even though recent surveys suggest an improvement in this trend over the past few years, the fact that the Economic Development of India in the past 3 decades that has been fueled by the growth of private companies that have exclusively or mostly been led by men is indisputable (Korreck, 2019). Subsequent surveys have placed India amongst a group of countries where female entrepreneurs, politicians, and professionals face an unfair playing field due to pronounced cultural biases, and a lack of business resources such as finances, capital, training, and development (Mastercard, 2018). The exclusion of women from economic activity and leadership positions costs India's GDP 6.8\% of its value (Khera, 2018). Entrepreneurship 


\section{International Journal of Social Science and Economic Research}

ISSN: $2455-8834$

Volume:05, Issue:10 "October 2020"

does just only enhance economic activity, innovation, and productivity in a particular society, but it is also a means for individuals to break free from uniform and dominant market practices, and achieve some level of emancipation and ability to make changes to the socio-economic surroundings. The formulation of effective strategies and policies that negate the impact of sociocultural barriers to female entrepreneurship necessitates their thorough analysis and the determination of regressive narratives upon which they stand.

\section{Background}

The structural barriers that are faced by women in entrepreneurship is a reflection of the larger system of Brahmanical Patriarchy that is dominant in India. Its consequences are similar to western patriarchal social structures, in terms of exclusion of women from the workforce. However, its roots are intrinsically linked to caste. The primary role of women in society has been restricted historically by maintaining 'caste purity' (Ambedkar, 1932). Childbirth has forced women to assume the roles of not only homemakers and child rears, but also of agents who ensure the progression and purity of a family, sub-caste, and caste. This has significant implications on the agency of women to work- since these narratives forbid women from interacting with men of other castes. Brahmanical patriarchy has been the dominant social system in the subcontinent for centuries. However, the ethos of the constitution of the nationstate now known as India was built by progressive politicians and freedom fighters, most of whom partly or completely rejected these notions. Not only does the Indian Constitution guarantee equal social and economic rights to women, but it also provides for affirmative action in key areas including business and employment that are imperative to ensure the emancipation of women and gender equality. Despite the progressive nature of the constitution, Indian society continues to restrict women to their households. Even when families allow their daughters or daughters-in-law to accept jobs, their professional and career aspirations are blocked by a glass ceiling, and their sole purpose of work is manufactured to be generating income for their families. Women's safety, especially in workplaces and public spaces further deters women from taking up, let alone creating employment (Soni, 2016).

Different central and state governments have prioritized women's empowerment in their public policy. Most recently, the right-wing central government introduced the Beti Bachao, Beti Padao campaign, intending to promote education for the girl child and reduce increasing rates of female foeticide and infanticide in India (The Wire, 2020). The same government also launched the Start-Up India campaign in 2015 to promote domestic entrepreneurship, investment, and capital formation. As a part of this program, the government set aside Rs 10,000 crore as Fund of Funds that are to be made available to entrepreneurs through the state-owned Small Industries Development Bank of India (Financial Express, 2018). 10\% of these funds have been reserved for women-led startups. In 2018, The Ministry of Micro, Small and Medium Enterprises 


\section{International Journal of Social Science and Economic Research}

ISSN: 2455-8834

Volume:05, Issue:10 "October 2020"

launched a portal called Udyam Sakhi for female entrepreneurs that provides them with information about incubation facilities, technical expertise around developing business models, and marketing low-cost products and services. Targeted at women from low-income communities, it aims to reduce the socio-economic inequities in the business environment of India (PIB, 2018)

Despite these policies, the literature suggests that the development of female entrepreneurship in India continues to be slow (Thomas, 2016). According to the Sixth Economic Census, only 14\% of a women-run or own businesses. More importantly, only $11 \%$ of the total business in India are owned by female entrepreneurs (MSPI, 2014). India is also ranked 52nd out of 57 countries in an index that studies financial access, advancement outcomes, and ease of doing business for women (Financial Express, 2018). Research by Shah \& Saurabh concludes that women in India face more difficulties in starting businesses as compared to other nations in South Asia (Shah \& Saurabh, 2018). This can be attributed to not only prevailing social conditions but also to the failure of public policies. The Beti Bachao Beti Padhao program, for example, spent 56.27\% of the funds allocated to it amounting to Rs 364.66 crore on advertising. In comparison to that, only $19 \%$ of the funds were allocated to districts and states to supplement empowerment initiatives (The Wire, 2020). The paucity of female entrepreneurs can be linked to the lack of presence of women in top management positions (only 9\% positions are occupied by women), and the declining participation of women in the workforce (Korreck, 2019).

\section{Discussion}

Establishing a business in India is a complex challenge for individuals regardless of their gender, primarily due to intense competition in the market, and irregular (too many or too few) regulations in specific industries. However, women face considerably a higher number of barriers in a male-dominated business environment. Research suggests that gender bias and discrimination tends to increase as women move higher up in an organization (Korreck, 2019). It is important to understand that this discrimination and exclusion is subtle, and not explicit. Regulations and laws prevent workplaces from actively discriminating against female employees, which leads to the formation of informal 'Boys Clubs' that restrict the growth potential of women in workplaces through regressive cultures, norms, practices, and traditions (King \& Jones, 2016). Automatic associations to these norms allow men to enhance their networks, which women are usually excluded from. Misogynist behavior ranging from implicit discrimination to sexual assault have tarnished the image of the Indian startup sector (Sathe, 2018). Research also suggests that there exists a 'Confidence Gap' between men and women, which is a result of narratives that surround both these genders (Kay \& Shipman, 2014). Media and culture in India have established men as enterprising and economically vigilant individuals, whereas women from a young age are advised against being assertive and taking risks. These 


\section{International Journal of Social Science and Economic Research}

ISSN: $2455-8834$

Volume:05, Issue:10 "October 2020"

narratives implicitly solidify self-perceptions of individuals, which are often harder to break down than regressive social narratives. The psychological impact of the confidence gap implies fewer entrepreneurial initiatives by women through their careers (Kay \& Shipman, 2014). This also leads to a lower tendency amongst women to choose their academic specializations in business.

Finance is the most important prerequisite for starting a company. Stereotypes and negative social narratives restrict access of women to some of the most viable and economically beneficial sources of finance. Women in Indira rarely own property, which can be used as collateral for loans. Families are also less likely to offer money to men to start businesses as compared to women. Despite these figures, about $79 \%$ of women-led startups are self-financed, which is testimony to the bias that influences investors and venture capitalists (Matthew, 2019). Fewer female entrepreneurs approach investors or are reluctant to divest stakes. Most of them who do take that risk in a hypermasculine environment are perceived differently than men. It has been concluded that investors prefer pitches presented by men as compared to those by women, even if the content is literally identical (Brooks, et. al., 2014). The family structure of India, which is again formed along with patriarchal beliefs and principles further deters the growth of female entrepreneurship. Even when women are working, society assumes that the primary responsibilities of the household lie with them, which translates into women restricting their time commitments to their careers and workplaces (WEF, 2018). Research suggests that women spend, on average, five times as much time than men on housework, household care, and other unpaid activities. The responsibility of childcare almost exclusively lies in women with social expectations from both genders being drastically different. The burden of not just conceiving but also rearing children actively deters women from taking the time out to start a business (Florida \& Hathaway, 2018).

It is also important to understand the differential impacts of these socio-economic and cultural forces in the diverse contexts of India. Tamil Nadu, Kerala, Andhra Pradesh, West Bengal, and Maharashtra lead the charts in female entrepreneurship figures- primarily due to their higher levels of economic development and social progression (Kay \& Shipman, 2014). Regions that are economically less-developed (Himachal Pradesh, Jharkhand, and the North-Eastern States) and those that perform poorly in women's empowerment (Uttar Pradesh, Bihar, and Haryana) have the lowest rates of female entrepreneurs. The most important markers that determine the nature and severity of structural barriers faced by women are class and caste, which determine access to education, healthcare, skill development, and most importantly government welfare schemes. Despite the criminalization of caste discrimination, it continues to prevail in society, even in public offices. Officials responsible for rendering services to people at the grassroots level are also complicit in perpetuating caste-hierarchies. Research suggests that the share of 


\section{International Journal of Social Science and Economic Research}

ISSN: $2455-8834$

Volume:05, Issue:10 "October 2020"

ownership of small businesses has declined over the past two decades for the Scheduled Caste and Scheduled Tribe communities. Most female-led startups in India have been established by Savarna women, and they outnumber the number of enterprises established by all members of backward and oppressed castes (Sharma \& Deshpande, 2013). This alludes to the presence of multiple layers of oppression that target different women differently based on their other social identity markers. Lastly, the lack of public safety for women, especially in developed cities like Delhi, restricts access to business opportunities and prevents women from setting up their entrepreneurial ventures (Soni, 2016).

\section{Conclusion}

Despite the presence of inequities and structural barriers for women, there has been significant progress in women's entrepreneurship in certain sectors over the past few years. This is important because it allows us to understand the nature of policy interventions that are useful in the Indian context. The availability of microfinance and the growth of Self-Help Groups have given a considerable push to female entrepreneurship, especially in economically less-developed regions of the country. $98 \%$ of businesses owned by women are micro-enterprises, with about $90 \%$ of them operating in the informal sector (Khera, 2018). There is a need to integrate microenterprises with the formal economy of India. Not only will this allow them to benefit from business and finance opportunities, but also protect them through regulations, which are enforced better in the formal economy. Scaling up of micro-enterprises is a key challenge, but can be accomplished through providing technical, financial, and marketing assistance. Public Microfinance programs and Self-Help Groups should be encouraged to pay special attention to the needs of Dalit women entrepreneurs, given the additional barriers they face in accessing finance from conventional sources (Sharma \& Deshpande, 2013). Doing away with discrimination that stems from both caste and gender in the supply chain, market spaces, and business cooperatives through awareness campaigns as well as punitive measures can provide a safety net to entrepreneurs, which is imperative to ensure and promote risk-taking behavior.

Role models are key to promoting positive career choices, which includes entrepreneurship. Promoting women to higher positions within established organizations to show how glass ceilings can be broken, can be instrumental in dealing with the Confidence Gap that restricts the growth of women's entrepreneurial initiatives. Promoting education and skill development amongst women is another key challenger that yields effective results. Affirmative action through the reservation of seats and lower fees for female students promotes enrollment in higher education. The overall percentage of women at the most prestigious business schools in India (the top 6 IIMs) has increased from 26\% to 33.5\% between 2019 and 2020 (Verma, 2018). This can partially be attributed to the reservation of seats for women in these institutions, which were previously male-dominated. 


\section{International Journal of Social Science and Economic Research}

ISSN: $2455-8834$

Volume:05, Issue:10 "October 2020"

Promoting entrepreneurship amongst women is an important part of the larger fight for emancipation and gender equality in India. In a free market where social progress and development is linked to economic prosperity, promoting entrepreneurship amongst women can lead to the normalization of the idea of female leaders, and women in positions of power- which is considered to be alien and taboo according to traditional patriarchal principles. There is no doubt that progress has been made, but it is important to ensure that this progress reaches women from backward castes and low-income communities, and benefits them- since they more often than not face the worst consequences of the system of Brahmanical Patriarchy.

\section{Bibliography}

Ambedkakr, B.R. (1932). The Annihilation of Caste.

Brooks A.W., Huang, L., Kearney, S.W., and Murray, F.E. (2014). Investors Prefer Entrepreneurial Ventures Pitched by Attractive Men. Proceedings of the National Academy of Sciences of the United States of America

Diochon, M., and Anderson, A. R. (2011). Ambivalence and ambiguity in social enterprise; narratives about values in reconciling purpose and practices. International Entrepreneurship and Management Journal.

Florida, R., and Hathaway, I. (2018). Rise of the Global Startup City: The New Map of Entrepreneurship and Venture Capital. Centre for American Entrepreneurship.

Financial Express. Modi's Startup India to give funding, incubation, more to these many womenrun businesses. 17th December 2019

Kay, K. and Shipman, C. (2014). The Confidence Gap. The Atlantic

Khera, P. (2018). Closing Gender Gaps in India: Does Increasing Womens' Access to Finance Help? IMF Working Paper

King, E., and Jones, K. (2016). Why Subtle Bias is so Often Worse than Blatant Discrimination. Harvard Business Review

Korreck, S. (2019). Women Entrepreneurs in India: What is Holding Them Back? Observer Research Foundation

Mastercard (2011). Mastercard Index of Women Entrepreneurs.

Mathew, A. (2019).“Making It in India. IMF Finance \& Development 
International Journal of Social Science and Economic Research

ISSN: 2455-8834

Volume:05, Issue:10 "October 2020"

Ministry of Statistics and Programme Implementation (2014). All India Report of Sixth Economic Census. Government of India

Press Information Bureau. Udyam Sakhi Portal Launched for Women Entrepreneurs. Ministry of Micro,Small \& Medium Enterprises. 8th March 2018

Sathe, G. Flipkart's Binny Bansal's Resignation is Startup India's Moment of Reckoning. Huffington Post. 14th November 2018.

Shah, H., and Saurabh, P. (2018). Women Entrepreneurs in Developing Nations: Growth and Replication Strategies for Poverty Alleviation. Technology Innovation Management Review

Sharma, C.K. (2011). A Discursive Dominance Theory of Economic Reform Sustainability: The Case of India. India Review.

Sharma, S. and Deshpande, A. (2013). Entrepreneurship or Survival? Caste and Gender of Small Business in India. Working Paper No. 228 Centre for Development Economics

Soni, M. (2016). Rethinking the Challenge of Women's Safety in India's Cities. Observer Research Foundation Issue Brief

The Wire. Govt Spent Most 'Beti Bachao, Beti Padhao' Funds on Advertisements. 8th March 2020

Thomas, A.E. (2016). Analysing the Growth of Women Entrepreneurship in India.

Primax International Journal of Commerce and Management Research

World Bank. (2014). Firms with Female Participation in Ownership. World Bank Enterprise Survey

World Economic Forum. (2018). The Global Gender Gap Report 2018. 